\title{
THE CORRECTNESS OF THE CAPM-MODEL APPLICATION IN THE UKRAINIAN REALITY IN TERMS OF INVESTORS FINANCIAL SECURITY*
}

\author{
Liudmyla Zakharkina', Maryna Abramchuk ${ }^{2}$ \\ Sumy State University, Ukraine
}

\begin{abstract}
Purpose. The purpose of this article is the research of correctness of CAPM-model application in the Ukrainian stock market and the analysis of the time factor's influence on the results of this model application. This problem acquires a special relevance for the provision of the investors' financial security, who act in the conditions of significant uncertainty and high risk of the Ukrainian stock market. Methodology. In this work, methods of dynamic lines' analysis, statistical, structural, comparative, correlation-regressive analysis were used. As the initial data during the research of profitability of the Ukrainian enterprises' shares, the data of the exchanging prices of the Ukrainian emitters' securities, according to the results of the trades in the Public JSC "Ukrainian Exchange", were used. Results. Contemporary approaches to the CAPM-model application in the markets, which are being developed, were analysed. As the result of this analysis, it was revealed that most of the scientific researches in this area emphasize incorrectness and unreliability of the results as to the prediction of the profitability indexes on such markets. Calculation of the $\beta$-coefficient for the Ukrainian emitters' securities for the various investments' horizon periods was done. The results of the calculation showed that the value of the $\beta$-coefficient varies greatly on the terms of investment and is not of the strictly consistent pattern. Stock market profitability per month based on UX-index and considering the investment horizon period was calculated. The expected profitability of the Ukrainian emitters' securities was distinguished and compared to their real rate of returns. During the profitability analysis in the investment intervals, exponential moving average with its further shift for a month was used. It gave an opportunity to distinguish an average monthly profitability in the various investment horizon periods ( 1 till 12 months). Practical significance. The application of the suggested approach can become an additional technique for the estimation of the investment attractiveness of securities of the stock market emitters in the various investment horizon periods that, in its turn, will increase the safety of such investment. Conclusions. The conclusion was made as to the correctness of the CAPM-model application in the Ukrainian reality, according to which it is almost impossible to define the exact regularity of the behaviour of indexes of the expected and real profitability depending on the investment horizon period. It casts doubt on the possibility of the appropriate and correct application of the CAPMmodel in the Ukrainian stock market. This conclusion, in general, coincides with the conclusions of many scientists, who conducted similar researches in the stock markets of other developing countries.
\end{abstract}

Key words: stock market, profitability, beta-coefficient, stock index, investment horizon.

JEL Classification: G10, G14

\section{Introduction}

One of the widely-discussed topics of the stock market is the issue of the manifold definition of the relation of profitability to risks, that is common for different financial investment tools. Investigation of this point started in the 1950s (Markowitz, 1952;
Sharpe, 1964) and was developed later by such wellknown scientists and experts (Treynor, 1962; Lintner, 1965; Mossin, 1966; Black, Jensen, Scholes, 1972) and others and, as the result of their scientific researches, the contemporary model of the capital assets estimation (CAPM) was formed. Later, this model was corrected

${ }^{1}$ Department of Finance and Entrepreneurship, Sumy State University.

E-mail: 1.zaharkina@finance.sumdu.edu.ua

${ }^{2}$ Department of Finance and Entrepreneurship, Sumy State University.

E-mail:m.abramchuk@finance.sumdu.edu.ua

\footnotetext{
* This work was supported by the Ministry of Education and Science of Ukraine (Project No. 0117U003922 "Innovative drivers of national economic security: structural modelling and forecasting")
} 
and modified considering different conditions of the stock markets.

Despite the huge quantity of the research papers in this sphere, there appears the necessity to check the possibility of the application of the CAPM-model in the Ukrainian stock market, which is much more fluctuating and unstable then contemporary European markets, according to the studies (Zakharkin, Zakharkina, Antoniuk, 2017). Especial interest in such studies is paid to the problem of considering investment horizon period, as in the majority of the research works the profitability of the market tools is measured annually, though at the same time very often financial investors work within much shorter investment periods. The reasons for this are fast movement and fluctuating of the contemporary stock markets that make investors re-structure investment portfolio.

Thus, the research works in this field are very relative. They go in line with "Complex Program of Development of Ukrainian Financial Sector till 2020”, the main purpose of which is the creation of the financial system that is able to provide stable economic development by means of effective re-distribution of the financial resources in the economics based on the development of the appropriate market competitive environment according to the EU standards.

The aim of the study is a study of the correctness of the CAPM-model application in the Ukrainian stock market and influence of the time factors on the results of this model application.

The subject of the study is theoretical, methodical, and practical aspects of the CAPM-model application in the Ukrainian stock market based on the estimation of the profitability indexes of the securities, which, in its turn, is an indicator of the decision-making for the financial investors.

\section{Analysis of the global approaches to the CAPM-model application}

Active investigations as to the possibilities of application of CAPM-model and its modifications go back to the 1970s, among which one can distinguish classical works (Black, Jensen, Scholes, 1972; Fama, French, 1992), which the background and the main issues of this model were settled. The further scientific works of this sphere were devoted to the critical analysis of the model and ways of its improvement. For example, in the paper (Roll, 1977), the issues of market portfolio and assessment of its profitability were examined. As the portfolio, the appropriate stock indexes were used. Along with that, the choice of such portfolio will influence on the result of the calculation of the $\beta$-coefficient, and consequently, the total result of the application of this model. The issues of the distinguishing of the $\beta$-coefficient, which is the key characteristic of the CAPM-model and problems of its stability, are examined in the works (Levy, 1971, Blume, 1975, Scholes, Williams 1977). Researches of these scientists showed irregularity of the approach, on which the calculation of $\beta$-coefficient was based, for the prediction of future profitability and risks of the financial actives - definite shares. Along with that, for the investment portfolio, the value of the $\beta$-coefficient is quite stable and tends to one with time that means that the risk tends to the mid-market rate.

Recently, studies of the possibilities and special features of the CAPM-model application in the developing markets became widely spread. Along with this, the majority of the authors emphasize the incorrectness and unreliability of the results as to the expected profitability indexes in such markets. This is explained by the difficulties of definition and substantiation of the basic characteristics of the model (riskless profitability, expected market profitability, $\beta$-coefficient) because of the underdevelopment of appropriate stock markets, absence of their informational effect, specific set of risks, that is characteristic to the developing economies.

Very important factor, which influences the results of the CAPM-model application, is the orientation on the investment horizon periods, issues of consideration of which were studied in works (Merton, 1973; Harvey, 1989; Robertson, Wright, 1998; Ibbotson, Chen, 2002; Gibson, 2013) and by others. The results of the researches of these scientists, which were conducted on the factual basis of American stock market, showed that in different investment horizon periods, there exist different interconnections between profitability and risks of financial assets, which differ greatly both within the type of assets (shares, stocks, treasury bills) and within duration of investment horizon periods.

Similar investigations were conducted by the Russian scientists (Berzon 2014; Abramov, Radygin, Chernova 2015, Boyarskiy 2016), who, taking as an example young developing Russian market (which is very much alike with Ukrainian one), analysed the time factors of influence on the profitability and risk in the stock market and came to various and sometimes controversy conclusions, as to the investment attractiveness of different financial tools.

Among Ukrainian scientists, who made a valuable impact into the development of methodology and practice of decision of stated above problems, one can distinguish works (Diakonov, Oleksich, 2010; Zavorotnii, 2014; Kukhta, 2005; Lukianenko, 2007).

Despite the presence of these and other publications, the actual absence of the studies of the behaviour of CAPM-model components in Ukrainian stock market substantiates the relevance of this paper. The issue of the influence of investment horizon periods on the CAPMmodel characteristics and, first of all, on the value of $\beta$-coefficient, which measures the securities' volatility relative to the mid-market risks. 


\section{Application of concepts of the CAPM-model to the securities of Ukrainian emitters}

As it is known, CAPM-model characterizes the process of formation of the market price on definite securities (other objects of real and financial investments) in conditions of the perfect capital market and considering systematic risks, which are not diversified. According to it the expected asset profitability, that is assets portfolio, is equal to the sum of riskless interest rate and awards for the investment risks in the definite asset, which is defined as the multiplication of the systematic risk level, characteristic for this asset and midmarket award for risks (Sharpe, 1964; Capital Asset Pricing Model):

$$
r_{i}=r_{f}+\left(r_{m}-r_{f}\right) \cdot \beta_{i}
$$

where $r_{i}$ - expected profitability of i-asset;

$r_{f}$ - profitability of the riskless asset;

$r_{m}$ - expected market profitability;

$\beta_{i}-\beta$-coefficient of $i$-asset, which estimates the rate of its profitability to the fluctuations of the market profitability (Mertens, 1997), or measures the systematic risks (market risk).

$\beta$-coefficient can be calculated relatively to the definite shares, other investment objects or investment portfolio. To calculate $\beta$-coefficient, it is necessary to process statistical data, which characterize variations (fluctuations) of the efficiency of the chosen investment object for several previous periods, riskless interest rate, and an average profitability of the market portfolio. For this, it is necessary to calculate such indexes:

- Mean square (standard) deviation of values of analysed asset's efficiency in the definite periods from the average asset efficiency during the studied period;

- The correlation coefficient, strong connection between the rate of profitability of the studied asset and the average rate of profitability in the market in general; - Mean square (standard) deviation of the profitability of the investments (RM) in the market in general (Capital Asset Pricing Model).
The commonly-known equation for the calculation of the $\beta$-coefficient can be written as follows (Kojefficient beta. Formula. Sovremennye modifikacii):

$$
\beta=\frac{\operatorname{Cov}\left(r_{i}, r_{m}\right)}{\sigma_{m}^{2}}
$$

where $r_{i}$ - profitability of $i$-asset;

$r_{m}$ - market profitability;

$\sigma_{m}^{2}$ - distribution of the market profitability.

At this, asset profitability and market profitability are defined according to the data of historical observations. As the input data during the examination of profitability of Ukrainian enterprises shares, the data about the stock rates of Ukrainian emitters' securities according to the results of the trades in the JSC "Ukrainian Exchange" were used. For calculation of historical data of the market profitability, the UX index of Ukrainian shares was used. Calculations were based on the five-year period from 1 January till 31 December 2016. On this horizon period, the studies were conducted in such possible investment intervals: $1,2 \ldots 12$ months. In the profitability analysis in the investment intervals, exponential moving average with its further shift for 1 month was used. Such an investigation technique was chosen considering the existing analogue approach presented in works by (Berzon 2014; Boyarskiy 2016) and by other scientists. Calculation of market tools' profitability per month was done with the help of formula:

$$
r_{i n}=\frac{\left(I_{i}-I_{0}\right)}{I_{0} \cdot t} \times 100
$$

where $r_{i m}$ - profitability per month in $i$-period;

$I_{i}$ - securities exchange rate (UX index) at the beginning of investment period;

$I_{0}$ - securities exchange rate (UX index) at the end of investment period;

$t$ - the number of months in the investment period.

$\beta$-coefficient calculation for various investment horizon periods was done using the possibilities of Excel program. For example, for the Public JSC Raiffeisen

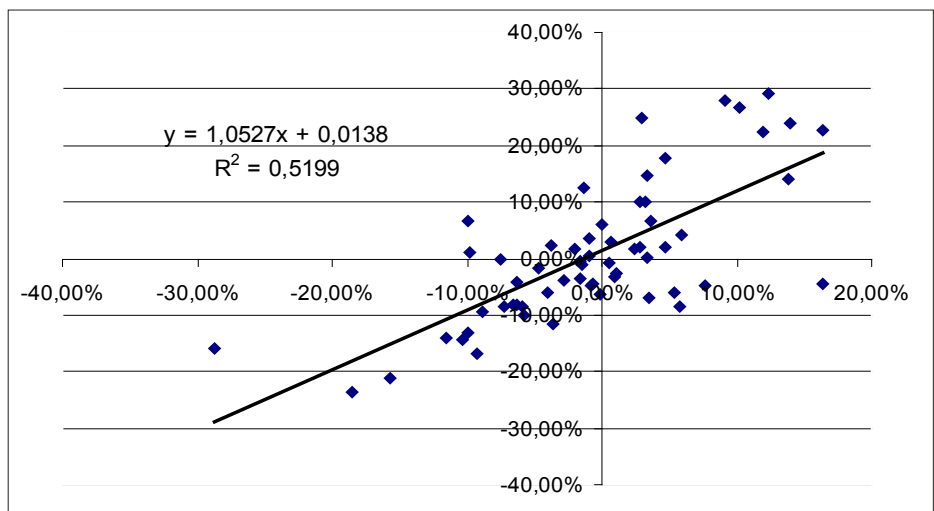

Fig. 1. Results of the $\beta$-coefficient calculation for the Public JSC Raiffeisen Bank Aval for the investment horizon period 1 month (2012-2016)

Source: compiled by the authors 
Bank Aval, the results of the $\beta$-coefficient calculations for the investment horizon period 1 month is the following (presented in Fig. 1). B-coefficient is equal to 1,0527.

Similar calculations were done for 10 Ukrainian securities emitters for various investment horizon periods. Results of the calculations are presented in Table 1 .

The further investigation of the correctness of application of the CAPM-model in Ukrainian market was conducted by calculation of the expected profitability of the Ukrainian emitters' securities using Formula 1 and comparing it to the actual profitability indexes (ria), which were shown by the securities in 2017. At this, as the riskless profitability, there was accepted the profitability of the bond certificate of domestic government loan (BCDGL), which was equal to $14 \%$ annually in 2017 (in hryvnia), which constitutes $1.17 \%$ monthly.
The procedure of distinguishing the expected profitability in Formula 1 settles definite questions. Generalizing the contemporary scientificmethodological approaches to the definition of such profitability and considering that this investigation is based on its actual indexes for 2017, there was calculated the monthly profitability based on the UX-index and considering investment horizon periods. Calculation results are presented in Table 2.

Thus, substituting the stated above data into Formula 1, the expected value of the listed above Ukrainian emitters' securities for 2017 was calculated and it was compared to the real profitability of the securities in various investment horizon periods - from 1 till 12 months. The results of these calculations are stated in Table 3. The difference between the real and expected profitability presents the coefficient $a\left(a_{i}\right)$,

Table 1

$\beta$-coefficients of the Ukrainian emitters' securities in various investment horizon periods (based on 2012-2016 data)

\begin{tabular}{|c|c|c|c|c|c|c|c|c|c|c|c|c|}
\hline \multirow{2}{*}{ Emitters' securities } & \multicolumn{12}{|c|}{ Investment horizon periods (months) } \\
\hline & $1 \mathrm{~m}$. & $2 \mathrm{~m}$. & $3 \mathrm{~m}$. & $4 \mathrm{~m}$. & $5 \mathrm{~m}$. & $6 \mathrm{~m}$. & $7 \mathrm{~m}$. & $8 \mathrm{~m}$. & $9 \mathrm{~m}$. & $10 \mathrm{~m}$. & $11 \mathrm{~m}$. & $12 \mathrm{~m}$. \\
\hline PJSC Raiffeisen Bank Aval & 1,05 & 1,22 & 1,24 & 1,32 & 1,39 & 1,42 & 1,49 & 1,54 & 1,60 & 1,68 & 1,74 & 1,84 \\
\hline PJSC "Ukrsotsbank" & 0,72 & 0,50 & 0,41 & 0,39 & 0,33 & 0,41 & 0,45 & 0,46 & 0,49 & 0,53 & 0,57 & 0,58 \\
\hline PJSC “Ukrtelekom” & 0,38 & 0,64 & 0,64 & 0,61 & 0,65 & 0,63 & 0,58 & 0,53 & 0,46 & 0,47 & 0,42 & 0,39 \\
\hline $\begin{array}{l}\text { PJSC “DTEK } \\
\text { Dniprooblenerho" }\end{array}$ & 0,11 & 0,37 & 0,39 & 0,57 & 0,81 & 0,99 & 1,12 & 1,24 & 1,75 & 2,25 & 2,25 & 2,59 \\
\hline $\begin{array}{l}\text { PJSC “DTEK } \\
\text { Dneproenergo" }\end{array}$ & 0,66 & 0,93 & 0,79 & 0,90 & 1,17 & 1,40 & 1,56 & 1,76 & 2,04 & 2,28 & 2,33 & 2,43 \\
\hline PJSC "Centrenergo" & 1,14 & 1,22 & 1,19 & 1,15 & 1,16 & 1,13 & 1,15 & 1,13 & 1,11 & 1,05 & 1,01 & 0,98 \\
\hline PJSC "MOTOR SICH" & 0,85 & 0,78 & 0,74 & 0,66 & 0,59 & 0,58 & 0,57 & 0,58 & 0,56 & 0,55 & 0,55 & 0,55 \\
\hline PJSC “Ukrnafta” & 1,36 & 1,54 & 1,62 & 1,64 & 1,70 & 1,76 & 1,72 & 1,63 & 1,56 & 1,47 & 1,39 & 1,28 \\
\hline $\begin{array}{l}\text { PJSC "Kryukov Railway } \\
\text { Car Building Works" }\end{array}$ & 0,69 & 0,67 & 0,62 & 0,60 & 0,63 & 0,66 & 0,64 & 0,61 & 0,60 & 0,60 & 0,57 & 0,53 \\
\hline $\begin{array}{l}\text { PJSC "Automobile } \\
\text { Company" Bogdan Motors" }\end{array}$ & 1,09 & 1,51 & 1,67 & 1,64 & 1,75 & 1,65 & 1,58 & 1,48 & 1,37 & 1,32 & 1,19 & 1,14 \\
\hline
\end{tabular}

Source: compiled by the authors

Table 2

Monthly profitability of Ukrainian stock market in 2017 (based on the UX index) in various horizon periods, \%

\begin{tabular}{|c|c|c|c|c|c|c|c|c|c|c|c|}
\hline \multicolumn{10}{|c|}{ Investment horizon periods (months) } \\
\hline $1 \mathrm{~m}$. & $2 \mathrm{~m}$. & $3 \mathrm{~m}$. & $4 \mathrm{~m}$. & $5 \mathrm{~m}$. & $6 \mathrm{~m}$. & $7 \mathrm{~m}$. & $8 \mathrm{~m}$. & $9 \mathrm{~m}$. & $10 \mathrm{~m}$. & $11 \mathrm{~m}$. & $12 \mathrm{~m}$. \\
\hline 4,61 & 4,51 & 4,34 & 4,03 & 3,96 & 4,19 & 4,27 & 4,19 & 4,42 & 4,91 & 5,32 & 5,80 \\
\hline
\end{tabular}

Source: calculated by the authors

Table 3

Expected and real monthly profitability of the Ukrainian emitters' securities in various investment horizon periods in $2017, \%$

\begin{tabular}{|c|c|c|c|c|c|c|c|c|c|c|c|c|c|}
\hline \multirow{2}{*}{\multicolumn{2}{|c|}{ Emitters' securities }} & \multicolumn{12}{|c|}{ Investment horizon periods (months) } \\
\hline & & \multirow{2}{*}{$\frac{1 \mathrm{~m} .}{4,80}$} & \multirow{2}{*}{$\begin{array}{l}2 \mathrm{~m} . \\
5,24\end{array}$} & \multirow{2}{*}{$\begin{array}{l}3 \mathrm{~m} . \\
5,10 \\
\end{array}$} & \multirow{2}{*}{$\begin{array}{l}4 \mathrm{~m} . \\
4,95\end{array}$} & \multirow{2}{*}{$\begin{array}{l}5 \mathrm{~m} . \\
5,04\end{array}$} & \multirow{2}{*}{$\begin{array}{l}6 \mathrm{~m} . \\
5,47\end{array}$} & \multirow{2}{*}{$\begin{array}{l}7 \mathrm{~m} . \\
5,78\end{array}$} & \multirow{2}{*}{$\begin{array}{l}8 \mathrm{~m} . \\
5,83\end{array}$} & \multirow{2}{*}{$\begin{array}{l}9 \mathrm{~m} . \\
6,38\end{array}$} & \multirow{2}{*}{$\frac{10 \mathrm{~m} .}{7,45}$} & \multirow{2}{*}{$\frac{11 \mathrm{~m} .}{8,39}$} & \multirow{2}{*}{$\frac{12 \mathrm{~m} .}{9,68}$} \\
\hline & $r_{i}$ & & & & & & & & & & & & \\
\hline PJSC Raiffeisen Bank & $r_{i a}$ & 7,89 & 8,53 & 8,92 & 7,54 & 6,99 & 7,44 & 7,85 & 7,90 & 8,61 & 9,98 & 9,83 & 9,95 \\
\hline & $a_{i}$ & 3,09 & 3,30 & 3,82 & 2,59 & 1,94 & 1,97 & 2,07 & 2,07 & 2,23 & 2,53 & 1,44 & 0,27 \\
\hline \multirow{3}{*}{ PJSC “Ukrsotsbank” } & $r_{i}$ & 3,65 & 2,83 & 2,48 & 2,27 & 2,08 & 2,42 & 2,58 & 2,57 & 2,77 & 3,13 & 3,52 & 3,84 \\
\hline & $r_{i a}$ & 3,37 & 3,43 & 3,53 & 2,95 & 2,68 & 2,57 & 2,53 & 2,75 & 3,12 & 3,72 & 3,63 & 3,51 \\
\hline & $a_{i}$ & $-0,27$ & 0,61 & 1,04 & 0,67 & 0,61 & 0,15 & $-0,05$ & 0,18 & 0,35 & 0,59 & 0,11 & $-0,33$ \\
\hline
\end{tabular}


Vol. 4, No. 1, 2018

Baltic Journal of Economic Studies

End of Table 3

\begin{tabular}{|c|c|c|c|c|c|c|c|c|c|c|c|c|c|}
\hline \multirow{3}{*}{ PJSC “Ukrtelekom” } & $r_{i}$ & 2,48 & 3,30 & 3,18 & 2,90 & 2,98 & 3,06 & 2,98 & 2,76 & 2,67 & 2,91 & 2,93 & 2,99 \\
\hline & $r_{i a}$ & 0,77 & 0,37 & 0,85 & 1,23 & 1,10 & 1,11 & 1,13 & 1,08 & 1,09 & 0,74 & 0,12 & 0,29 \\
\hline & $a_{i}$ & $-1,72$ & $-2,93$ & $-2,33$ & $-1,67$ & $-1,88$ & $-1,95$ & $-1,85$ & $-1,68$ & $-1,58$ & $-2,17$ & $-2,81$ & $-2,70$ \\
\hline \multirow{3}{*}{$\begin{array}{c}\text { PJSC “DTEK } \\
\text { Dniprooblenerho" }\end{array}$} & $r_{i}$ & 1,55 & 2,42 & 2,41 & 2,79 & 3,43 & 4,15 & 4,65 & 4,90 & 6,86 & 9,59 & 10,51 & 13,18 \\
\hline & $r_{i a}$ & 16,57 & 19,00 & 17,93 & 20,44 & 22,38 & 23,10 & 25,56 & 30,36 & 27,00 & 20,50 & 20,99 & 13,01 \\
\hline & $a_{i}$ & 15,01 & 16,58 & 15,51 & 17,65 & 18,95 & 18,96 & 20,91 & 25,45 & 20,14 & 10,90 & 10,47 & $-0,17$ \\
\hline \multirow{3}{*}{$\begin{array}{l}\text { PJSC “DTEK } \\
\text { Dneproenergo" }\end{array}$} & $r_{i}$ & 3,45 & 4,28 & 3,66 & 3,74 & 4,44 & 5,40 & 6,02 & 6,48 & 7,80 & 9,69 & 10,84 & 12,43 \\
\hline & $r_{i a}$ & 15,07 & 18,34 & 21,32 & 25,64 & 28,77 & 26,92 & 24,54 & 25,51 & 23,72 & 18,47 & 17,14 & 19,43 \\
\hline & $a_{i}$ & 11,62 & 14,06 & 17,65 & 21,90 & 24,33 & 21,52 & 18,52 & 19,03 & 15,92 & 8,79 & 6,29 & 6,99 \\
\hline \multirow{3}{*}{ PJSC "Centrenergo" } & $r_{i}$ & 5,10 & 5,25 & 4,95 & 4,46 & 4,41 & 4,59 & 4,75 & 4,59 & 4,76 & 5,09 & 5,38 & 5,73 \\
\hline & $r_{i a}$ & 1,88 & 1,21 & 0,82 & 0,57 & 0,65 & 0,86 & 0,88 & 0,68 & 0,56 & 0,75 & 1,12 & 1,86 \\
\hline & $a_{i}$ & $-3,22$ & $-4,04$ & $-4,13$ & $-3,89$ & $-3,76$ & $-3,74$ & $-3,87$ & $-3,91$ & $-4,20$ & $-4,34$ & $-4,26$ & $-3,87$ \\
\hline \multirow{3}{*}{ PJSC “MOTOR SICH” } & $r_{i}$ & 4,08 & 3,77 & 3,53 & 3,07 & 2,80 & 2,92 & 2,94 & 2,90 & 2,99 & 3,24 & 3,45 & 3,71 \\
\hline & $r_{i a}$ & 6,09 & 5,88 & 5,57 & 5,67 & 5,70 & 5,79 & 5,94 & 6,10 & 6,35 & 6,61 & 7,38 & 8,25 \\
\hline & $a_{i}$ & 2,01 & 2,11 & 2,04 & 2,60 & 2,90 & 2,87 & 3,00 & 3,20 & 3,35 & 3,37 & 3,93 & 4,54 \\
\hline \multirow{3}{*}{ PJSC “Ukrnafta” } & $r_{i}$ & 5,87 & 6,32 & 6,32 & 5,85 & 5,91 & 6,48 & 6,52 & 6,10 & 6,23 & 6,68 & 6,93 & 7,10 \\
\hline & $r_{i a}$ & 3,04 & 2,99 & 2,32 & 2,35 & 2,66 & 2,81 & 2,74 & 2,55 & 2,29 & 2,07 & 2,62 & 2,69 \\
\hline & $a_{i}$ & $-2,82$ & $-3,33$ & $-4,00$ & $-3,50$ & $-3,25$ & $-3,68$ & $-3,78$ & $-3,55$ & $-3,94$ & $-4,61$ & $-4,30$ & $-4,41$ \\
\hline \multirow{3}{*}{$\begin{array}{l}\text { PJSC "Kryukov Railway } \\
\text { Car Building Works" }\end{array}$} & $r_{i}$ & 3,56 & 3,42 & 3,15 & 2,87 & 2,94 & 3,17 & 3,16 & 3,02 & 3,12 & 3,41 & 3,52 & 3,62 \\
\hline & $r_{i a}$ & 1,96 & 0,65 & 0,48 & 0,67 & 0,31 & 0,42 & 0,43 & 0,28 & 0,57 & 0,39 & 0,50 & 1,64 \\
\hline & $a_{i}$ & $-1,60$ & $-2,77$ & $-2,67$ & $-2,21$ & $-2,63$ & $-2,74$ & $-2,73$ & $-2,74$ & $-2,56$ & $-3,02$ & $-3,02$ & $-1,99$ \\
\hline \multirow{3}{*}{$\begin{array}{l}\text { PJSC "Automobile } \\
\text { Company" Bogdan } \\
\text { Motors" }\end{array}$} & $r_{i}$ & 4,92 & 6,21 & 6,49 & 5,86 & 6,05 & 6,16 & 6,08 & 5,65 & 5,63 & 6,12 & 6,09 & 6,47 \\
\hline & $r_{i a}$ & 3,34 & 1,77 & 1,08 & 0,64 & 0,93 & 0,97 & 1,08 & 0,93 & 0,44 & 0,79 & 1,20 & 2,64 \\
\hline & $a_{i}$ & $-1,58$ & $-4,44$ & $-5,41$ & $-5,22$ & $-5,12$ & $-5,18$ & $-5,00$ & $-4,71$ & $-5,19$ & $-5,33$ & $-4,89$ & $-3,83$ \\
\hline
\end{tabular}

Source: calculated by the authors

which characterize the excess profitability witness about the underestimation or overestimation of the financial assets (Mertens, 1997).

\section{Conclusions}

Summarizing the conducted research, it can be stated that the application of the CAPM-model in Ukrainian stock market does not give the reliable results in any investment horizon period. The closest to the real value expected profitability result was shown by the shares of the emitters of the bank group - Public JSC Raiffeisen Bank Aval and Public JSC “Ukrsocbank”. The securities of all other investigated Ukrainian emitters are characterized by the great value deviation of the real profitability from the expected one that is proved by the high value of the coefficient $\alpha$, which, sometimes, gets abnormal values (for example: Public JSC "DTEK Dniprooblenergo" and Public JSC "DTEK Dniproenergo"). At this, it is almost impossible to state the clear consistency of behaviour of indexes of expected and real profitability depending on the investment horizon periods. It casts doubt on the possibility of the adequate and correct application of the CAPM-model in Ukrainian stock market. This conclusion, in general, coincides with the conclusions of many scientists, who conducted similar studies in the stock markets of other developing countries.

Considering what is stated above, the perspective of the further researches is an attempt to adapt the CAPMmodel to Ukrainian realities, through taking into account the factors, which influence the profitability of the securities in Ukrainian stock market.

\section{References:}

Markowitz, H. (1952). Portfolio selection. The Journal of Finance, 7(1), 77-91. Retrieved from https://www.math.ust.hk/ maykwok/courses/ma362/07F/markowitz_JF.pdf (in Eng.)

Sharpe, W. F. (1964). Capital Asset Prices: A Theory of Market Equilibrium under Conditions of Risk. Journal of Finance, 19, 425-442. (in Eng.)

Treynor, J. L., (1962). Toward a Theory of Market Value of Risky Assets, Unpublished manuscript. A final version was published in 1999, in Asset Pricing and Portfolio Performance: Models, Strategy and Performance Metrics. Robert A. Korajczyk (editor) London: Risk Books, pp. 15-22. (in Eng.)

Lintner, J. (1965). The Valuation of Risk Assets and the Selection of Risky Investments in Stock Portfolios and Capital Budgets. The Review of Economics and Statistics, 47(1),13-37. (in Eng.)

Mossin, J. (1966). Equilibrium in a Capital Asset Market. Econometrica, 34(4), 768-783. (in Eng.) 
Black, F., Jensen, M.C., \& Scholes, M. (1972). The Capital Asset Pricing Model: Some Empirical Tests. Studies in the theory of capital markets. New York : Praeger Publishers Inc., 54. Pages Posted: 13 Jun 2006 . - Retrieved from http://www.efalken.com/LowVolClassics/blackjensenscholes.pdf (in Eng.)

Zakharkin, O., Zakharkina, L., \& Antoniuk, N. (2017). A comparative analysis of stock market volatility depending on investment time horizon. Economic Annals-XXI, 167(9-10), 49-52. https://doi.org/10.21003/ea.V167-10 (in Eng.) Kompleksna prohrama rozvytku finansovoho sektoru Ukrainy do 2020 roku [Complex program of Ukrainian financial sector development till 2020]. (2015) Revised by the solution of the National Bank of Ukraine Administration on 16 Jan 2018, № 28. Retrieved from https://bank.gov.ua/doccatalog/document?id=43352266 (in Ukrainian)

Fama, E.F., \& French, K. R. (1992). The Cross-Section of Expected Stock Returns. Journal of Finance, 47(2), 427-65. - Retrieved from https://www.ivey.uwo.ca/cmsmedia/3775518/the_cross-section_of_expected_stock_ returns.pdf (in Eng.)

Roll, R. (1977). A critique of the asset pricing theory's tests Part I: On past and potential testability of the theory. Journal of Financial Economics, 4(2), 129-176. (in Eng.)

Levy, R.A. (1971). On the short-term stationarity of beta coefficients. Financial Analysts Journal, 27(6), 55-61. (in Eng.) Blume, M.E. (1975). Betas and then regression tendencies. Journal of Finance, 30(3), 785-795. Retrieved from http://www.stat.ucla.edu/ nchristo/statistics417/blume_betas.pdf (in Eng.)

Scholes, M., \& Williams J. (1977). Estimating betas from nonsynchronous data. Journal of Financial Economics, 5(3), 309-327. (in Eng.)

Merton, R. (1973). Theory of rational option pricing. Bell Journal of Economics and Management Science, 4(1), 141-183. Retrieved from http://www.people.hbs.edu/rmerton/Theory\%20of\%20Rational\%200ption\%20 Pricing.pdf (in Eng.)

Harvey, C.R. (1989).Time-varying conditional covariance's in tests of asset pricing models. Journal of Financial Economics, 24(.2), 289-317 (in Eng.)

Robertson, D. \& Wright S. (1998). The good news and the bad news about long-run stock market returns (working paper). University of Cambridge..pdf Retrieved from https://www.repository.cam.ac.uk/bitstream/handle/1810/412/ stocks? sequence=1\&isAllowed $=y$ (in Eng.)

Ibbotson, R. \& Chen, P. (2002). Stock Market Returns in the Long Run: Participating in the Real Economy (Yale ICF working paper № 0.00-44). Yale School of Management. Retrieved from https://papers.ssrn.com/sol3/papers. cfm?abstract_id=274150 (in Eng.)

Gibson, R. (2013). Asset Allocation: Balancing Financial Risk : Fifth Edition . N. Y.: McGraw-Hill Education LLC (in Eng.)

Berzon, N. I. (2014). Ocenka finansovyh aktivov po kriteriju «risk-dohodnost $\gg s$ uchetom dlitelnosti investirovanija [Assessment of financial assets by the ratio of "risk-yield", taking into consideration the duration of investments]. Vestnik Moskovskogo universiteta imeni S. Ju. Vitte. Serija 1: Jekonomika i upravlenie - Moscow Witte University Bulletin. Series 1: Economics and Management, 2(8), 39-52. Retrieved from https://www.muiv.ru/vestnik/pdf/eu/ eu_2014_2_039-052.pdf(in Russian)

Abramov, A., Radygin, A. \& Chernova, M. (2015). Dolgosrochnye portfelnye investicii: novyj vzgljad na dohodnost i riski [Long-Term Portfolio Investment: New Insight into Return and Risk]. Voprosy jekonomiki - Voprosy Ekonomiki, 10, 54-77 (in Russian)

Boyarskiy, A. (2016). Faktor vremeni v ocenke jeffektivnosti portfelnyh investicij na rossijskom fondovom rynke [Time factor in the estimation of the indirect investment efficiency in the Russian stock market]. http://abnsecurities. blogspot.com/Retrieved from http://abnsecurities.blogspot.com/2016/03/blog-post.html (in Russian)

Diakonov, K.M. \& Oleksich, D. V. (2010). Mekhanizm urakhuvannia vplyvu ryzykiv na otsinku finansovykh instrumentiv za dopomohoiu beta-koefitsiienta [Process of consideration of influence of the risks on the estimation of financial assets with the help of $\beta$-coefficient]. Zbirnyk naukovykh prats Cherkaskoho derzhavnoho tekhnolohichnoho universytetu. Seriia : Ekonomichni nauky - Collected Works "ChSTU Bulletin. Series: Economics", 22(2), 127-130. (in Ukrainian)

Zavorotnii, R. I. (2014). Problemy otsinky ryzykovosti emitentiv na finansovykh rynkakh [Problems of the betaratios valuation of the enterprises on financial markets]. Finansy Ukrainy - Finance of Ukraine, 6, 49-62. (in Ukrainian) Kukhta,P.V.(2005). Perspektyvyvykorystannia modeli tsinoutvorennia na rynku kapitaliv u prak-tytsi otsiniuvannia vartosti vlasnoho kapitalu pidpryiemstv Ukrainy [Outlooks of pricing model application in the assets market in the practice of estimation of the price of the Ukrainian enterprises private capital]. Visnyk Kyivskoho natsionalnoho universytetu imeni Tarasa Shevchenka. Seriia "Ekonomika" - Bulletin of Taras Shevchenko National University of Kyiv. Economics", 74, 36-38. (in Ukrainian)

Lukianenko, I. H. (2007). Otsinka kapitalnykh aktyviv u finansovomu menedzhmenti [Estimation of capital assets in financial management]. Naukovi zapysky NaUKMA. Seriia Ekonomichni nauky - Scientific Papers NaUKMA. Economics, 68, 47-52. (in Ukrainian)

Capital Asset Pricing Model (CAPM). Retrieved from http://buklib.net/books/22595/\#_ftnref1 (in Ukrainian) Mertens, A. V. (1997). Investicii: Kurs lekcij po sovremennoj finansovoj teorii [Investment: course of lectures on modern financial theory]. Kiev:: Investment agensy of Kiev (in Russian)

Kojefficient beta. Formula. Sovremennye modifikacii [ $\beta$-coefficient. Formula. Modern modifications]. Retrieved from http: / / finzz.ru/koefficient-beta-formula-raschet-v-excel.html (in Russian)

Sait Ukrainskoi birzhi [Site of Ukrainian Exchange]. Retrieved from http://www.ux.ua/ua/ (in Ukrainian) 